\title{
PHYSICAL TRAITS AND NUTRITIONAL QUALITY OF SELECTED SERBIAN MAIZE GENOTYPES DIFFERING IN KERNEL HARDNESS AND COLOUR
}

\author{
Marija S. Milašinović Šeremešić* ${ }^{1}$, Milica M. Radosavljević ${ }^{2}$ Jelena Ž. Srdić ${ }^{2}$, \\ Zorica M. Tomičić ${ }^{1}$, Olivera M. Đuragić ${ }^{1}$ \\ ${ }^{1}$ University of Novi Sad, Institute of Food Technology in Novi Sad, 21000 Novi Sad, \\ Bulevar cara Lazara1, Serbia \\ ${ }^{2}$ Maize Research Institute „Zemun Polje“,11000 Belgrade Slobodana Bajića 1, Serbia
}

\author{
${ }^{*}$ Corresponding author: \\ Phone: +381214853752 \\ E-mail address: marija.milasinovic@fins.uns.ac.rs
}

\begin{abstract}
Physical quality traits (1000-kernel weight, density, milling response and soft endosperm portion), basic chemical (starch, protein, oil, cellulose and ash) and amino acids composition of ten ZP maize genotypes differing in kernel hardness and colour were studied. The objectives of this study were to characterize differences in ZP maize genotypes regarding to various physical traits and nutritional quality parameters such as basic chemical and amino acid composition and the data was correlated to find the interrelationship between these parameters. Kernel physical traits and chemical composition significantly varied among tested genotypes. A significant negative correlation was found between protein content and portion of soft endosperm as well as a significant positive correlation between protein content and two physical traits, milling response and density. Protein content showed a non-significant negative correlation with starch content. The results showed that the protein content exhibited negative correlation with lysine as well as positive correlation with methionine. It has not been observed a significant improvement in the amino acid composition regarding the specialty genotypes such as the selected white and red kernels and popping maize genotypes. The information presented in this study could be useful for the utilization improvement of maize kernel and the development of maize-based ingredients to prepare nutritious feed and food products.
\end{abstract}

Keywords: corn, endosperm, physical traits, chemical composition, amino acids, variation

\section{INTRODUCTION}

Variations in maize quality occur because of various estimable and inestimable factors, including environment, agricultural practice, genetics, growing and post harvesting conditions, kernel chemical composition, kernel physical traits, etc. (Harrigan et al., 2007; Radosavljević et al., 2000, 2010; Wang et al., 2008a).

Typical chemical composition for the commodity yellow dent maize kernel on a dry matter basis is $71.7 \%$ starch, $9.5 \%$ pro- tein, $4.3 \%$ oil, $1.4 \%$ ash, and $2.6 \%$ sugar (Watson, 2003). Nutritional quality of maize oil and protein can be improved by altering their fatty acid and amino acid composition. Maize kernel is primary source of energy for domestic animal nutrition as well as very important source of energy for humans. Starch is its major nutritional and energetic component providing up to 68 to 74 percent of the kernel weight. The maize kernel is also an im- 
portant source of dietary proteins. However, compared to legume seeds, its nutritional quality is poor due to deficiency of two essential amino acids, lysine and tryptophan. Although the germ protein has adequate lysine content $(5.4 \%)$ in whole kernel, this is diluted by the much more abundant endosperm proteins, which have an average lysine content of only about $1.9 \%$. This is because $60-70 \%$ of endosperm protein consists of zeins, which contain few or no lysine residues (Coleman and Larkins, 1999). Similarly, the absence of tryptophan residues in zein proteins is the reason for the low tryptophan content of maize protein. However, amino acid contents in maize endosperm can be improved by mutant selection (Muehlbauer et al., 1994) or genetic engineering (Huang et al., 2006). Breeding for quality protein maize would have the added advantage of biofortification of maize. Wild relatives have been regarded as a source to extend the genetic diversity of maize breeding programs.

Maize kernel is also a source of oil which is highly regarded for human consumption as it reduces the blood cholesterol concentration (Dupont et al., 1990). Chemical composition in maize kernel is genetically controlled, and the presence of genetic diversity is essential for maize quality and utilization improvement (Radosavljević et al., 2010). In addition, physical kernel traits may have an effect on nutritive value of maize. Previous research indicated that maize hardness is in relationship to physical kernel traits and subsequently with ruminal starch availability (Correa et al., 2002), feed efficiency of feedlot cattle (Jaeger et al., 2006), and growth performance and carcass characteristics of pigs (More et al., 2008).

Due to the broad applications of maize kernel in various food and feed products, maize is very important source of the macronutrients ( $\mathrm{Ai}$ and Jane, 2016). In the past decades, much research effort has been undertaken to improve the nutritional quality of maize kernel for animal and human consumption.

The objectives of this study were to characterize differences in the selected ZP maize genotypes regarding to various physical traits (the parameters of kernel hardness) and nutritional quality parameters such as basic chemical and amino acid composition and the data was correlated to find the interrelationship between these parameters.

\section{MATERIALS AND METHODS}

Genetic material evaluated in the study included ten genotypes of different types (dent, semi-dent and flint) and colour (yellow, red and white) of maize kernel. Kernels were collected in full maturity stage from plants that received the same management practices grown in a field-trial at the Maize Research Institute „Zemun Polje" under the semi-arid condition in 2016 growing season. The experiment was set up by a random block design (RCB) with three blocks.

\section{Physical quality traits}

The 1000-kernel weight was evaluated by counting and weighting of $4 \times 250$ of unbroken kernels.

Kernel density. Approximately $33 \mathrm{~g}$ of whole kernels was weighed to $\pm 0.001 \mathrm{~g}$. Volume determinations were then made with a Beckman model 930 air-comparison pycnometer. Procedures for using the aircomparison pycnometer are described by Thompson and Isaacs (1967). The analyses was performed in three replicates.

The kernel hardness was measured by Stenvert-Pomeranz method by milling a $20 \mathrm{~g}$ of maize kernels in micro hammermill at $3600 \mathrm{rpm}$ and 2-mm sieve (Pomeranz et al., 1985). Results were expressed as milling response and soft endosperm portion (\%). The milling response presents the time (s) necessary for kernel grinding until the top level of the material collected in a glass cylinder $(125 \times 25$ $\mathrm{mm}$ ) reaches the level of $17 \mathrm{~mL}$. The test was performed in three replicates.

\section{Basic chemical composition}

The starch content was determined by Ewers polarimetric method (ISO, 1997). Dry matter content in the maize flour was determined by the standard drying method in an oven at $105{ }^{\circ} \mathrm{C}$ to constant mass. Oil concentration was determined according 
to the Soxhlet method (AOAC, 2000). Protein content was estimated as the total $n-$ itrogen by the Kjeldahl method multiplied by 6.25 , and the ash content was determined by slow combustion of the sample at $650{ }^{\circ} \mathrm{C}$ for $2 \mathrm{~h}$ (AOAC, 1990). Crude fibre content was determined by Weende method adjusted for Fibretec ${ }^{\mathrm{TM}}$ Systems, Foss, Denmark (ISO, 1993).

\section{Amino acid profiles}

The amino acids analyses of maize kernel were performed using ion exchange chromatography with utilization of Automatic Amino Acid Analyzer Biochrom 30+ (Biochrom, Cambridge, UK), according to Spackman et al. (1958). The technique was based on amino acid separation using strong cation exchange chromatography, followed by the ninhydrin colour reaction and photometric detection at 570 $\mathrm{nm}$ and $440 \mathrm{~nm}$ (for proline). Samples were hydrolysed in $6 \mathrm{M} \mathrm{HCl}$ (Merck, Germany) at $110{ }^{\circ} \mathrm{C}$ for $24 \mathrm{~h}$, and then cooled to room temperature. After hy-drolysis, samples were filtered and made up to $25 \mathrm{~mL}$ in Sodium Loading Buffer $(\mathrm{pH}$ 2.2) (Biochrom, Cambridge, UK). Sub-sequently, prepared samples were filtered through $0.22 \mu \mathrm{m}$ pore size PTFE filter (Plano, Texas, USA) and the filtrate was transferred to an HPLC vial (Agilent Technologies, USA).

The retention time of the peak on the chromatogram identifies the amino acid and the area under the peak indicates the quantity of amino acid present. The results were expressed as grams of amino acid in $100 \mathrm{~g}$ of dry weight.

\section{Statistical analysis}

All chemical analyses were performed in three replications, and the results were statistically analyzed. A factorial analysis of variance (ANOVA) for trials was conducted using randomized complete block (RCB) design. Treatment means were tested using Tukey HSD test to determine the significant differences between group means in an analysis of variance setting at an alpha-level of 0.05 . Pearson's product moment correlation coefficient was used for determining correlations between the estimated traits and Principal Component
Analysis (PCA) to summarize the data of traits in fewer variables (the PC-axis or factors) and show which traits are close to each other, i.e., which carry comparable information. Hierarchical cluster analysis was used to group the hybrid into classes or clusters based on their similarities. All statistical analyses were done by the STATISTICA program package 13.3 (StatSoft Inc., 2018).

\section{RESULTS AND DISCUSSION}

Maize kernel hardness has been shown to have an influence on the efficiency of production or quality of the final product. In terms of maize physical traits, 1000-kernel weight, absolute density, milling response and proportion of soft and hard endosperm fraction have all been linked to hardness and subsequent effects on processing.

Maize genotypes used in this study were selected by different traits of their kernel endosperm and colour: yellow kernel dent, ZP 333; red kernel dent, ZP 333c; yellow kernel semi-dent, ZP 366; red kernel semi-dent ZP 366c; white kernel dent, ZP 553b; yellow kernel dent, ZP 555; yellow kernel dent, ZP 606; yellow kernel flint, ZP $611 \mathrm{k}$; yellow kernel flint, ZP $614 \mathrm{k}$; and white kernel semi-dent ZP 775b. The data for physical quality traits and basic chemical composition in the kernel of different ZP maize genotypes are given in Table 1.

Among the genotypes, there were significant variations in the all physical traits. 1000-kernel weight of 10 different ZP maize genotypes ranged from 128.40 to $376.50 \mathrm{~g}$, and the density, as an important physical quality trait of kernel, ranged from

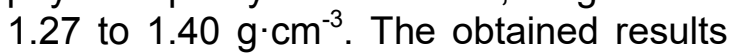
of the Stenvert test (milling response) ranged from 12.10 to $25.40 \mathrm{~s}$.

The portion of the soft endosperm fraction in total milled material showed a similar tendency as a milling response, and ranged from 23.72 to $46.71 \%$. The genotypes analysed by Radosavljevic et al. (2000) comprised dent, high oil, waxy, white endosperm, flint, and popcorn genotypes, which showed great variability for hardness. 
Significant variation among the genotypes has been observed in the starch, protein, oil and cellulose contents. The total content of starch, protein, oil, cellulose and ash ranged from $64.55-68.96 \%, 8.13-$ $11.21 \%, \quad 3.58-4.46 \%, \quad 2.14-2.78 \%$ and $1.11-1.36 \%$, respectively. In addition to the popcorns (ZP 611k, ZP 614k), two ZP maize genotypes with yellow kernel, ZP 366 and ZP 606, had higher protein content (approximately 10\%). The highest content of starch was found in two yellow genotypes, ZP 333 and ZP 366 (approximately $69 \%$ ). The specialty genotypes (white, red kernels and popping maize genotypes) had lower starch content.

Table 1.

Kernel physical quality traits and chemical composition of different ZP maize genotypes

\begin{tabular}{|c|c|c|c|c|c|c|c|c|c|}
\hline \multirow[b]{2}{*}{$\begin{array}{l}\text { Maize } \\
\text { Genotypes }\end{array}$} & \multicolumn{4}{|c|}{ Physical quality traits ${ }^{c}$} & \multicolumn{5}{|c|}{ Chemical composition $^{\mathrm{a}, \mathrm{c}}$} \\
\hline & $\begin{array}{c}1000- \\
\text { kernel } \\
\text { weight } \\
\text { (g) }\end{array}$ & $\begin{array}{l}\text { Density } \\
\left(\mathrm{gcm}^{-3}\right)\end{array}$ & $\begin{array}{l}\text { Milling } \\
\text { res- } \\
\text { ponse (s) }\end{array}$ & $\begin{array}{c}\text { Soft } \\
\text { endo- } \\
\text { sperm } \\
(\%)\end{array}$ & $\begin{array}{c}\text { Starch } \\
(\%)\end{array}$ & $\begin{array}{l}\text { Protein } \\
(\%)\end{array}$ & $\begin{array}{l}\text { Oil } \\
\text { (\%) }\end{array}$ & $\begin{array}{l}\text { Cellu- } \\
\text { lose } \\
(\%)\end{array}$ & $\begin{array}{l}\text { Ash } \\
\text { (\%) }\end{array}$ \\
\hline ZP 333 yellow & $345.45^{\mathrm{c}}$ & $1.28^{\mathrm{e}}$ & $12.60^{\mathrm{de}}$ & $46.71^{\mathrm{a}}$ & $68.82^{\mathrm{a}}$ & $8.91^{\mathrm{d}}$ & $4.07^{\mathrm{C}}$ & $2.25^{\mathrm{de}}$ & $1.28^{\mathrm{C}}$ \\
\hline ZP $333 c$ red & $359.49^{b}$ & $1.27^{\dagger}$ & $12.10^{\mathrm{e}}$ & $46.66^{\mathrm{a}}$ & $67.97^{\mathrm{a}}$ & $8.34^{\mathrm{et}}$ & $3.95^{\mathrm{d}}$ & $2.14^{\mathrm{e}}$ & $1.26^{\mathrm{a}}$ \\
\hline $\begin{array}{l}\text { ZP } 366 \\
\text { vellow }\end{array}$ & $351.52^{c}$ & $1.33^{b c}$ & $15.10^{\mathrm{bc}}$ & $38.49^{d}$ & $68.96^{a}$ & $10.14^{b c}$ & $4.42^{\mathrm{a}}$ & $2.78^{a}$ & $1.26^{\mathrm{d}}$ \\
\hline ZP 366c red & $374.28^{\mathrm{a}}$ & $1.31^{\mathrm{d}}$ & $13.77^{\mathrm{cde}}$ & $42.38^{\mathrm{b}}$ & $65.54^{\mathrm{b}}$ & $9.43^{\mathrm{c}}$ & $4.26^{\mathrm{b}}$ & $2.37^{d}$ & $1.26^{\mathrm{d}}$ \\
\hline ZP 553b white & $283.27^{\dagger}$ & $1.31^{\mathrm{cd}}$ & $16.33^{b}$ & $38.97^{\mathrm{d}}$ & $68.11^{\mathrm{a}}$ & $8.13^{\dagger}$ & $4.35^{\mathrm{b}}$ & $2.14^{\mathrm{e}}$ & $1.11^{\mathrm{e}}$ \\
\hline $\begin{array}{l}\text { ZP } 555 \\
\text { vellow }\end{array}$ & $333.94^{d}$ & $1.31^{\mathrm{cd}}$ & $14.37^{\mathrm{cd}}$ & $41.47^{\mathrm{bc}}$ & $68.25^{b}$ & $8.63^{\mathrm{de}}$ & $4.46^{a}$ & $2.35^{d}$ & $1.33^{b}$ \\
\hline ZP 606 yellow & $376.50^{\mathrm{a}}$ & $1.29^{\mathrm{e}}$ & $14.60^{\mathrm{bc}}$ & $41.00^{\mathrm{bc}}$ & $66.26^{\mathrm{b}}$ & $10.0^{\mathrm{bc}}$ & $3.94^{d}$ & $2.15^{\mathrm{e}}$ & $1.33^{\mathrm{b}}$ \\
\hline $\begin{array}{l}\text { ZP 611k } \\
\text { popcorn }\end{array}$ & $133.74^{g}$ & $1.40^{\mathrm{a}}$ & $25.40^{\mathrm{a}}$ & $24.45^{\mathrm{e}}$ & $64.55^{\mathrm{b}}$ & $11.21^{\mathrm{a}}$ & $4.03^{c}$ & $2.58^{\mathrm{bc}}$ & $1.26^{\mathrm{d}}$ \\
\hline $\begin{array}{l}\text { ZP 614k } \\
\text { popcorn }\end{array}$ & $128.40^{g}$ & $1.39^{a}$ & $25.07^{a}$ & $23.72^{\mathrm{e}}$ & $64.69^{b}$ & $9.96^{\mathrm{bc}}$ & $3.58^{e}$ & $2.73^{a b}$ & $1.29^{\mathrm{C}}$ \\
\hline ZP $775 b$ white & $307.72^{\mathrm{e}}$ & $1.32^{c}$ & $14.47^{\mathrm{c}}$ & $40.07^{\mathrm{cd}}$ & $65.12^{\mathrm{b}}$ & $8.83^{\mathrm{d}}$ & $4.31^{\mathrm{b}}$ & $2.41^{\mathrm{cd}}$ & $1.36^{\mathrm{a}}$ \\
\hline Min & 128.40 & 1.27 & 12.10 & 23.72 & 64.55 & 8.13 & 3.58 & 2.14 & 1.11 \\
\hline Max & 376.50 & 1.40 & 25.40 & 46.71 & 68.96 & 11.21 & 4.46 & 2.78 & 1.36 \\
\hline Mean & 299.43 & 1.32 & 16.38 & 38.39 & 64.55 & 9.36 & 4.14 & 2.39 & 1.27 \\
\hline$S d^{b}$ & 93.22 & 0.04 & 4.82 & 8.05 & 1.77 & 0.97 & 0.27 & 0.24 & 0.08 \\
\hline
\end{tabular}

${ }^{a}$ Calculated on dry matter basis;

${ }^{b} \mathrm{Sd}$-standard deviation;

${ }^{c}$ Means marked with a common letter are not significantly different at the $5 \%$ level of significance calculated by Tukey's HSD test

Table 2.

Amino acids profiles in the maize kernel of different ZP genotypes

\begin{tabular}{|c|c|c|c|c|c|c|c|c|c|c|c|c|}
\hline $\begin{array}{l}\text { Amino } \\
\text { acids }\end{array}$ & $\begin{array}{c}\mathrm{ZP} \\
333 \\
\text { yellow }\end{array}$ & $\begin{array}{c}\text { ZP } \\
333 c \\
\text { red }\end{array}$ & $\begin{array}{l}\text { ZP } 366 \\
\text { yellow }\end{array}$ & $\begin{array}{c}\mathrm{ZP} \\
366 \mathrm{c} \\
\text { red }\end{array}$ & $\begin{array}{c}\text { ZP } \\
553 b \\
\text { white }\end{array}$ & $\begin{array}{c}\mathrm{ZP} \\
555 \\
\text { yellow }\end{array}$ & $\begin{array}{c}\mathrm{ZP} \\
606 \\
\text { yellow }\end{array}$ & $\begin{array}{c}\text { ZP } \\
611 k \\
\text { pop- } \\
\text { corn }\end{array}$ & $\begin{array}{c}\text { ZP } \\
614 k \\
\text { pop- } \\
\text { corn }\end{array}$ & $\begin{array}{c}\text { ZP } \\
775 b \\
\text { white }\end{array}$ & Min & Max \\
\hline Asparagine & 6.72 & 6.93 & 6.65 & 6.88 & 6.83 & 7.12 & 7.05 & 6.25 & 7.03 & 6.99 & 6.25 & 7.12 \\
\hline Threonine & 3.53 & 3.64 & 3.85 & 3.48 & 3.77 & 3.47 & 3.81 & 3.94 & 3.63 & 3.46 & 3.46 & 3.94 \\
\hline Serine & 5.22 & 5.16 & 4.87 & 5.48 & 5.32 & 5.31 & 4.77 & 5.69 & 5.13 & 5.38 & 4.77 & 5.69 \\
\hline Glutamine & 18.3 & 18.48 & 17.09 & 18.88 & 17.84 & 17.76 & 17.61 & 17.24 & 19.09 & 17.64 & 17.1 & 19.1 \\
\hline Proline & 9.95 & 9.72 & 8.97 & 9.23 & 10.03 & 10.01 & 9.06 & 8.49 & 8.44 & 9.34 & 8.44 & 10.0 \\
\hline Glycine & 3.07 & 3.17 & 3.57 & 4.09 & 3.94 & 3.38 & 3.15 & 3.3 & 3.13 & 3.81 & 3.07 & 4.09 \\
\hline Alanine & 7.82 & 7.47 & 7.63 & 7.85 & 7.72 & 7.7 & 7.89 & 7.26 & 7.61 & 7.81 & 7.26 & 7.89 \\
\hline Cistine & 2.05 & 2.83 & 2.07 & 2.65 & 3.18 & 2.68 & 2.08 & 2.24 & 2.13 & 2.01 & 2.01 & 3.18 \\
\hline Valine & 5.71 & 5.36 & 4.41 & 4.64 & 4.01 & 4.78 & 4.86 & 5.23 & 5.34 & 5.16 & 4.01 & 5.71 \\
\hline Methionine & 2.48 & 2.32 & 3.19 & 2.91 & 2.28 & 2.59 & 2.27 & 3.24 & 2.83 & 2.68 & 2.27 & 3.24 \\
\hline Isoleucine & 3.22 & 3.09 & 3.44 & 3.01 & 3.63 & 3.2 & 3.45 & 3.23 & 3.11 & 3.19 & 3.01 & 3.63 \\
\hline Leucine & 9.54 & 10.18 & 10.53 & 11.62 & 9.92 & 10.99 & 10.55 & 10.53 & 11.65 & 10.62 & 9.54 & 11.7 \\
\hline Norleucine & 1.41 & 1.68 & 1.41 & 1.9 & 2.16 & 1.19 & 1.59 & 1.35 & 1.07 & 2.02 & 1.07 & 2.16 \\
\hline Tyrosine & 4.52 & 4.08 & 4.59 & 4.88 & 4.11 & 4.87 & 4.75 & 4.55 & 4.61 & 4.33 & 4.08 & 4.88 \\
\hline Lysine & 3.6 & 3.2 & 3.11 & 2.69 & 3.18 & 2.72 & 2.82 & 2.63 & 2.91 & 3.26 & 2.63 & 3.60 \\
\hline Histidine & 3.52 & 3.04 & 2.83 & 3.2 & 3.4 & 3.2 & 3.09 & 2.79 & 3.47 & 3.42 & 2.79 & 3.52 \\
\hline Arginine & 5.04 & 4.25 & 4.81 & 5.09 & 5.16 & 4.57 & 4.52 & 4.45 & 4.93 & 5.19 & 4.21 & 5.16 \\
\hline
\end{tabular}


Out of 20 amino acids, an animal or a human being can synthesise only nine of them (non-essential amino acids). The remaining amino acids (essential amino acids-EAA) should be provided by their various sources of food. Arginine is regarded as EAA in birds and fish. Therefore it is regarded as a semi-essential amino acid. Cysteine and tyrosine are also regarded as semi-essential amino acids, as they can be synthesised exclusively with methionine and phenylalanine, respectively (Boisen et al., 2000).

The amino acid profile of the selected maize genotypes is shown in Table 2 . Comparation of the maize genotypes revealed that the kernel is dominated with the amino acid glutamine (17.09-19.09\%), followed by proline (8.44-10.03\%) and leucine (9.54-11.65\%). Lysine and methionine concentrations among the maize genotypes were very low $(2.63-3.60 \%$ and $2.27-3.27 \%$, respectively). The obtained re-sults are in agreement with the results of the previous research (Wang et al., $2008 \mathrm{~b})$. The observed differences between the genotypes in amino acids composition are not clear enough due to the fact that in this paper we have not considered other factors (environment, management practices etc.) that could affect the quality of kernel protein. Previous research has showed that nitrogen is an im- portant macronutrient for development of amino acids and proteins in maize crop (CIMMYT, 2003). Different field conditions altered the ratio of maize genetic effects and suppress genetic effects for protein concentration (Kumar et al., 2018). The recent study demonstrated the critical value of $\mathrm{N}$ played an important role in tryptophan and lysine production of quality protein maize (QPM) hybrid. On the other hand, the extensive research of Scott et al. (2006) suggests that composition of maize hybrids has changed over time, while the quality of the protein (defined as methionine, lysine or tryptophan per protein) has not changed in a statistically detectable way. The authors found the kernel protein content of modern hybrids responds to plant density and environment differently than the protein content of older varieties. These differences may partially explain how modern hybrids can maintain yield in different environments, i.e. decrease of protein content in stressful environments frees resources that are used to maintain yield.

Based on the above, it has not been observed a significant improvement in the amino acid composition regarding the specialty genotypes such as the selected white (ZP 553b, ZP 775b) and red (ZP 333c, ZP 366c) kernels and popping maize (ZP 611k, ZP 614k) genotypes.

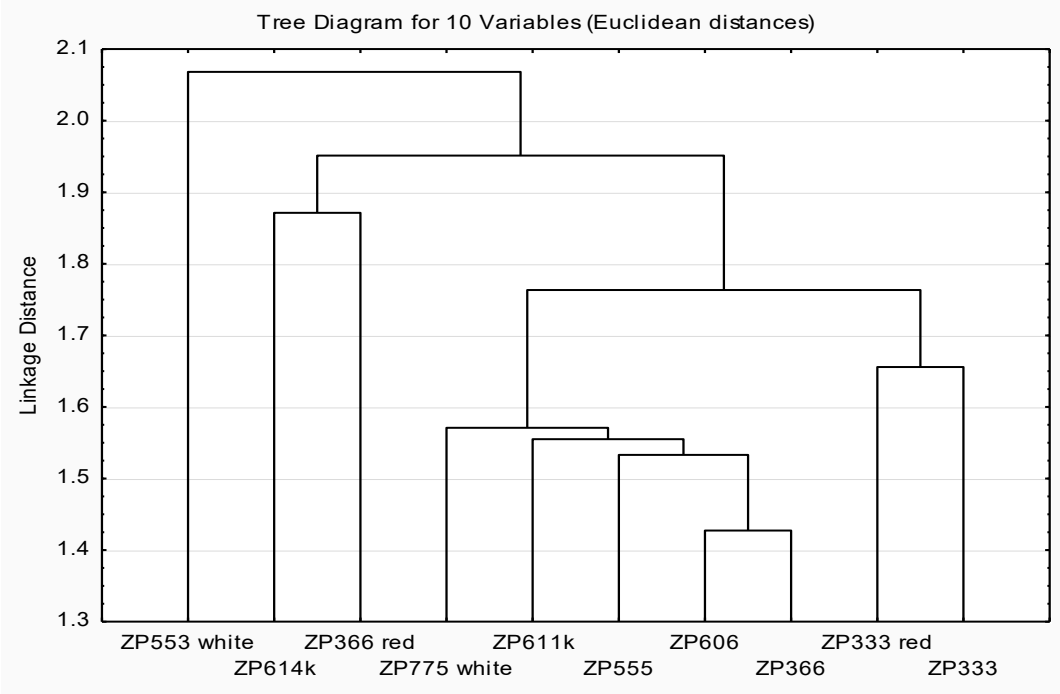

Figure 1. Dendrograms obtained from the hierarchical cluster analysis of each amino acid in maize kernel 
Table 3.

Pearson's product moment correlation coefficients between physical quality traits and chemical composition of different ZP maize genotypes

\begin{tabular}{lccccccccc}
\hline & KWt & Den & MRes & SE & Starch & Protein & Oil & Cellulose & Ash \\
\hline KWt & 1.00 & $-0.92^{*}$ & $-0.96^{*}$ & $0.94^{*}$ & 0.60 & -0.50 & 0.51 & -0.55 & 0.12 \\
Den & & 1.00 & $0.96^{*}$ & $-0.98^{*}$ & $-0.63^{*}$ & $0.69^{*}$ & -0.32 & $0.77^{*}$ & -0.02 \\
MRes & & & 1.00 & $-0.99^{*}$ & $-0.65^{*}$ & $0.67^{*}$ & -0.51 & 0.62 & -0.09 \\
SE & & & 1.00 & $0.66^{*}$ & $-0.69^{*}$ & 0.45 & $-0.69^{*}$ & 0.04 \\
Starch & & & & & 1.00 & -0.52 & 0.48 & -0.31 & -0.30 \\
Protein & & & & & & 1.00 & -0.34 & $0.66^{*}$ & 0.23 \\
Oil & & & & & & & 1.00 & -0.11 & -0.14 \\
Cellulose & & & & & & & & 1.00 & 0.19 \\
Ash & & & & & & & & & 1.00 \\
\hline
\end{tabular}

Marked correlations are significant at $p<0.05, N=10$

KWt - 1000-kernel weight; Den - density; MRes - milling response; SE - soft endosperm portion

The hierarchical cluster analysis (Figure 1) clearly shows four groups (clusters) of the genotypes which were differentiated on the basis of the similarity of amino acid profile. The genotypes were very good clustered according to their genetic background. The genotype ZP 553b has unrelated components with other genotypes. In their parental components, or maternal components, the genotypes ZP 366, ZP 606, ZP 555 and ZP 333 have a certain percentage of the genetic of the popcorn genotypes, therefore the popcorns are closely related to them. The genotypes ZP 333 and ZP 366 have the same maternal component. Obviously, there was no significant change in the amino acid composition of the red kernel of ZP 333c (compared with yellow kernel), as opposed to the genotype ZP 366, where the red kernel (ZP 366c) was grouped into the second subcluster. Relate to the white kernel genotype, ZP $775 \mathrm{~b}$, its maternal component contains a part of the germplasm that is close to the genetics of the genotypes ZP 606, ZP 555, ZP 333 and ZP 366.

Both starch and protein contents affected hardness. On the basis of correlation analysis and gained correlation coefficients (Table 3) very high dependences are noticed between kernel starch content and the physical quality traits such as Den, MRes and SE $\left(-0.63^{*},-0.65^{*}\right.$ and $\left.0.66^{*}\right)$. Protein content in maize kernel positively correlated with Den and MRes $\left(0.69^{*}\right.$ and $\left.0.67^{*}\right)$, and negatively correlated with SE $\left(-0.69^{*}\right)$. Further, the kernel cellulose content affected positively on density and the protein content $\left(0.77^{*}\right.$ and $\left.0.66^{*}\right)$ and ne- gatively on SE $\left(-0.69^{*}\right)$.

On the basis of the mentioned relationships it can be concluded that three physical quality traits, density, milling response and soft endosperm portion had the highest interdependence with the chemical quality parameters such as the kernel contents of starch, protein and cellulose of the selected materials. Maize genotypes with higher level of soft endosperm fraction in the whole kernel have higher starch content, and lower protein and cellulose content. Further, the increase in Den and MRes, resulted in the increase of the protein content and the decrease of the starch content.

The results have indicated the significance of the physical parameters which are closely related to the nutritive quality and the utility value of maize kernel. The results agree with our previous findings (Milašinović et al., 2007; and Semenčenko et al., 2013). Another important finding of this study is the negative (but not statistically significant) correlation between protein content and lysine content in kernel ($0.53)$ as well as the positive and significant correlation between protein content and methionine content $\left(0.74^{*}\right)$ (the data not shown).

On the PCA score plot, four groups of physical and chemical parameters are clearly separated. Compared to Pearson's product moment correlation PCA gives different perspectives over investigated traits. The correlation coefficients provide information about the strength of the association between two variables, while PCA provide orthogonal arrangement of variables and thus indicate their interrela- 


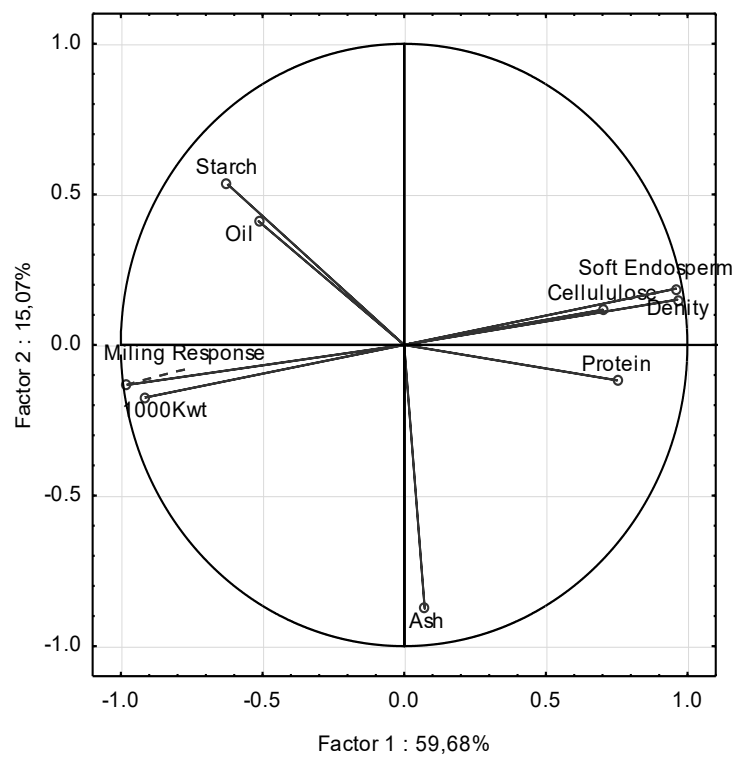

Figure 2. Principal component analysis loadings (similarities of 9 traits)

tion. Soft endosperm raction, cellulose, density and protein are correlated on one side and negatively correlated with milling response and 1000-kernel weight on the other side. Starch and oil content are grouped, and closely correlated with milling response and 1000-kernel weight but opposite from ash content (Figure 2). The first principal component, PC1, accounts for $59.68 \%$ of the total data variance, and the second PC2 account for $15.07 \%$. The separation of the investigated quality parameters is largely based on the first principal component.

The observed interactions have to be examined in a larger number of maize genotypes. Further research regarding to the inter-relationship among nutritional quality parameters of maize genotypes as well as the inter-relationship between physical quality traits and amino acids composition is necessary.

\section{CONCLUSIONS}

Kernel physical traits and chemical composition significantly varied among tested genotypes. This research confirms that the hardness (the combination of several physical quality traits) of maize kernel is very important criterion and clearly had significant interrelationship with chemical composition (starch, protein and cellulose contents) in maize kernel. Therefore hard- ness (some physical traits) could be used to predict nutritional quality and utility value of maize kernel. Regarding the specialty genotypes (white, red kernels and popping maize genotypes), no significant improvement in the amino acid composition has been observed. The information presented in this study could be useful for the development of maize-based ingredients to prepare nutritious feed and food products as well as could be a guidelines for maize breeders in terms of further research and improve-ment of maize properties for specific purpose.

\section{ACKNOWLEDGEMENTS}

This paper is a result of the research within two projects financed by the Ministry of Education, Science and Technological Development of the Republic of Serbia: 1. Project III 46012 "Study of modern biotechnological methods in the production of animal feed in order to increase competitiveness, quality and safety of the feed" ("Istraživanje savremenih biotehnoloških postupaka u prizvodnji hrane za životinje u cilju povećanja konkurentnosti, kvaliteta i bezbednosti hrane"), and 2. Project 31068 "Improvement of corn and soybean properties by molecular and conventional breeding" (Poboljšanje svojstava kukuruza i soje molekularnim i konvencionalnim oplemenjivanjem). 


\section{REFERENCES}

1. Ai, Y., Jane, J. (2016). Macronutrients in corn and human nutrition. Comprehensive Reviews in Food Science and Food Safety, 15, 581598.

2. (AOAC) Association of Official Analytical Chemists (2000). Official Methods of Analysis, $17^{\text {th }}$ international edition - AOAC International, Gaithersburg, MD., USA. Methods 923.03, 925.09, 930.15, 955.04, 960.39.

3. (AOAC) Association of Official Analytical Chemists (1990). Official Methods of Analysis, Ed. K. Herlich, AOAC, Arlington, VA, pp. 70-84.

4. Boisen, S., Hvelplund, T., Weisbjerg, M.R. (2000). Ideal amino acid profiles as a basis for feed protein evaluation. Livestock Production Science, 64, 239-251.

5. CIMMYT (2003). The development and promotion of quality protein maize in sub-Saharan Africa. Progress report submitted to Nippon foundation. CIMMYT, Mexico.

6. Coleman, C.E., Larkins, B.A. (1999). The prolamins of maize. In: Seed proteins, Eds. P.R. Shewry, R. Casey, Kluwer, Dordrecht, pp. 109-139.

7. Correa, C.E., Shaver, R.D., Pereira, M.N., Lauer, J.G., Kohnt, K. (2002.). Relationship between corn vitreousness and ruminal in situ starch degradability. Journal of Dairy Science, 85, 3008-3012.

8. Dupont, J., White, P.J., Carpenter, M.P., Schaefer, E.J., Meydani, S.N., Elson, C.E., Woods, M., Gorbach, S.L. (1990). Food uses and healtheffects of corn oil. Journal of the American College of Nutrition, 9, 438-470.

9. Fox, G., Manley, M. (2009). Hardness methods for testing maize kernels. Journal of Agricultural and Food Chemistry, 57, 56475657.

10. Harrigan, G.G., Stork, L.G., Riordan, S.G., Reynolds, T.L., Ridley, W.P., Masucci, J.D., Maclsaac, S., Halls, S.C., Orth, R., Smith, R.G., Wen, L., Brown, W.E., Welsch, M., Riley, R., McFarland, D., Pandravada, A., Glenn, K.C. (2007). Impact of genetics and environment on nutritional and metabolite components of maize grain. Journal of Agricultural and Food Chemistry, 55 (15), 6177-6185.

11. Huang, S., Frizzi, A., Florida, C.A., Kruger, D.E., Luethy, M.H. (2006). High lysine and high tryptophan transgenic maize resulting from the reduction of both 19 - and 22-kD alpha-zeins. Plant Molecular Biology, 61, 525535.

12. (ISO) International Organization for Standardization (1993). Agricultural food products. Determination of crude fibre. General method NF-V03-040 (status: certified standard ref. ISO 5498). Assn. Fr. De Normalisation, Paris.

13. (ISO) International Organization for Standardization (1997). Determination of starch content-Ewers polarimetric method. International Standard: ISO 10520
14. Jaeger, S.L., Luebbe, M.K., Macken, C.N., Erickson, G.E., Klopfenstein, T.J., Fithian, W.A., Jackson, D.S. (2006). Influence of corn hybrid traits on digestibility and the efficiency of gain in feedlot cattle. Journal of Animal Science, 84, 1790-1800.

15. Kumar, S., Sarkar, A., Singh, R.P., Singh, R. (2018). Agro-environmental consequences of quality protein maize (QPM) hybrid development with special emphasis of soil nitrogen management. Plant Archives, 18 (1), 147-157.

16. Milasinovic, M., Radosavljevic, M., Dokic, Lj., Jakovljevic, J. (2007). Wet-milling properties of ZP maize hybrids. Maydica, 52 (3), 289-292.

17. Moore, S.M., Stadler, K.J., Beitz, D.C., Stahl, C.H., Fithian, W.A., Bregendahl, K. (2008). The correlation of chemical and physical corn kernel traits with growth performance and carcass characteristics in pigs. Journal of Animal Science, 86, 592-601.

18. Muehlbauer, G.J., Gengenbach, B.G., Somers, D.A., Donovan, C.M. (1994). Genetic and amino-acid analysis of two maize threonine-overproducing, lysine-insensitive aspartate kinase mutants. Theoretical and Applied Genetics, 89, 767-774.

19. Pomeranz, Y., Czuchjowska, Z., Martin, C.R., Lai, F. (1985). Determination of corn hardness by Stenvert hardness tester. Cereal Chemistry, 62, 108-110.

20. Radosavljević, M., Milašinović Šeremešić, M., Terzić, D., Todorović, G., Pajić, Z., Filipović, M., Kaitović, Ž., Mladenović Drinić, S. (2012). Effects of hybrid on maize grain and plant carbohydrates. Genetika, 44 (3), 649-659.

21. Radosavljević, M., Bekrić, V., Božović, I., Jakovljević, J. (2000). Physical and chemical properties of various corn genotypes as a criterion of technological quality. Genetika, 32, 319-329.

22. Radosavljevic, M., Bekric, V., Milasinovic, M., Pajic, Z., Filipovic, M., Todorovic, G. (2010). Genetic variability as background for the achievements and prospects of the maize utilisation development. Genetika, 42 (1), 119136.

23. Scott, M.P., Edwards, J.W., Bell, C.P., Schussler, J.R., Smith, J.S. (2006). Grain composition and amino acid content in maize cultivars representing 80 years of commercial maize varieties. Maydica, 51, 417-423.

24. Semenčenko, V., Mojović, L., Đukić Vuković, A., Radosavljević, M., Terzić, D., MilašinovićŠeremešić, M. (2013). Suitability of some selected maize hybrids from Serbia for the production of bioethanol and dried distillers' grains with solubles. Journal of the Science of Food and Agriculture, 93 (4), 811-818.

25. Spackman, D.H., Stein, W.H., Moose, S. (1958). Automatic recording apparatus for use in the chromatography of amino acids. Analytical Chemistry, 30, 1190-1206.

26. STATISTICA (Data Analysis Software System) (2018). v.13.3., Stat-Soft, Inc., USA (www.statsoft.com). 
27. Thompson, R.A., Isaacs, G.W. (1967). Porosity determinations of grains and seeds with an air-comparison pycnometer. Transactions of the ASAE, 10, 693-696.

28. Wang, L., Xu, C., Qu, M., Zhang, J. (2008b). Kernel amino acid composition and protein content of introgression lines from Zea mays ssp. mexicana into cultivated maize. Journal of Cereal Science, 48, 387-393.

29. Wang, Z.H., Li, S.X., Malhi, S. (2008a). Effects of fertilization and other agronomic measures on nutritional quality of crops. Journal of the Science of Food and Agriculture, 88 (1), 7-23.

30. Watson, S.A. (2003). Description, development, structure and composition of the corn kernel. In Corn: Chemistry and Technology, $2^{\text {nd }}$ ed. Eds. J. White, L. Johnson, American Association of Cereal Chemists, St. Paul, MN, pp. 69-101.

\title{
ФИЗИЧКЕ КАРАКТЕРИСТИКЕ И НУТРИТИВНИ КВАЛИТЕТ ОДАБРАНИХ ГЕНОТИПОВА КУКУРУЗА ИЗ СРБИЈЕ РАЗЛИЧИТИХ У ТВРДОЋИ И БОЈИ 3PHA
}

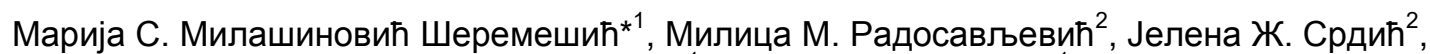 \\ Зорица М. Томичић ${ }^{1}$, Оливера М. Ђурагић ${ }^{1}$ \\ ${ }^{1}$ Универзитет у Новом Саду, Научни институт за прехрамбене технологије у Новом Саду, \\ 21000 Нови Сад, Булевар цара Лазара1, Србија \\ ${ }^{2}$ Институт за кукуруз „Земун Поље“,11000 Београд, Слободана Бајића 1, Србија
}

Сажетак: Испитиване су физичке карактеристике зрна (апсолутна маса или маса 1000 зрна, густина, отпорност на млевење и удео меке фракције ендосперма), основни хемијски састав (садржај скроба, протеина, уља, целулозе и пепела) и састав аминокиселина код 10 генотипова кукуруза различитих по тврдоћи и боји зрна. Циљеви овог рада били су да се изврши карактеризација ЗП генотипова кукуруза у односу на различите фиизичке особине и нутритивне параметре квалитета као што су основни хемијски и аминокиселински састав, и подаци потом корелационом анализом обраде у циљу утврђивања међуодноса ових параметара квалитета. Физичке особине зрна и хемијски састав значајно су варирали између испитиваних генотипова. Утврђена је значајна негативна корелација између садржаја протеина и удела меке фракције ендосперма као и значајне позитивне корелације између садржаја протеина и две физичке особине, отпорност на млевење и густина зрна. Садржај протеина показао је негативну корелацију са садржајем скроба. Резултати су показали да садржај протеина у зрну има негативну корелацију са садржајем лизина, као и позитивну корелацију са садржајем метионина. Није утврђено значајно побољшање састава аминокиселина код генотипова специфичних својстава, као што су генотипови белог и црвеног зрна, и генотипови кукуруза кокичара. Информације представљене у овом раду могу бити корисне за побољшање употребне вредности зрна кукуруза и развој компонената на бази кукуруза за храну за животиње и прехрамбене производе. варијација

Кључне речи: кукуруз, ендосперм, фризичке особине, хемијски састав, аминокиселине,

Received: 12 February 2019

Received in revised form: 29 March 2019

Accepted: 5 April 2019 